\title{
PENDEKATAN ILMU SOSIAL PROFETIK DALAM MEMAHAMI MAKNA AYAT-AYAT AL-QUR'AN
}

\author{
Irwanto \\ (Dosen PAI STIA Alma Ata Yogyakarta)
}

\begin{abstract}
Al-Quran as paradigm is the concepts that the moslems were able to make the Qur'an did construction of knowledge that allows us to understand the reality referred to the Qur'an itself. This means that the Qur'an construct knowledge which provides the basic for the action. It is allowing construction to construct a system, including system science. Thus Qur'an provided both an overview axiological and epistemological insight. In the islamic studies approach, a lot of methods that can be used as an analytical strategy to dissect the intricacies of Islam. One method that can be used is the prophetic social science approach. It was used to understand the meaning of the writer verses of the Qur'an. It was conceived and developed by Kuntowijoyo. This approach is more focused on aspects of empirical, historical, and temporal. Thus, it would be open the possibility of review, revision and reconstruction that may be present at any time and keep it to a text which became the study.
\end{abstract}

Keywords: Social Sciences, the verse of Al-Qur'an

\section{A. Pendahuluan}

Dalam ajaran Islam, segala bentuk tingkah laku ataupun amal perbuatan manusia harus berpedoman kepada hukum syara' (Al-Qur'an dan Al-Hadis), terlepas adanya sebagian kecil kaum muslimin yang menolak sumber Al-hadis dijadikan sebagai sumber hukum. Untuk memahami makna teks Al-Qur'an secara lebih proporsional, maka kaum muslim (yang tidak menggunakan bahasa Arab sebagai bahasa resmi) dituntut untuk bisa berbahasa Arab. Hal ini diperlukan agar lebih mudah menafsirkan ayat-ayat Al-Qur'an.

Penafsiran terhadap ayat-ayat Al-Qur'an sedikit banyak akan dipengaruhi oleh kondisi social masyarakat pada masa itu dan background pendidikan si mufasir tersebut. Permasalahan yang muncul, kemudian adalah hasil penafsiran atas ayat-ayat Al-Qur'an yang ia atau mereka lakukan kemudian dipaksakan kepada orang lain, bahkan tidak jarang, orang yang tidak menerima hasil penafsirannya tersebut dianggap sebagai kafir. Segala bentuk tindak tanduk perbuatan yang ia atau

LITERASI, Volume. V, No. 1 Juni 2014 
mereka lakukan dianggap sudah sesuai dengan apa yang diperintahkan oleh Allah, dan seringkali mereka menganggap orang yang berbeda pemahaman dengan mereka harus diperangi, dengan alasan untuk memurnikan kembali ajaran-ajaran Allah. Seringkali mereka lupa atau sengaja mengabaikan bahwa tidak ada kebenaran yang bersifat mutlak, apalagi dalam menafsirkan ayat-ayat Al-Qur'an.

Pemahaman ajaran Islam yang dangkal, mengakibatkan umat Islam terpecah-belah sekian lama. Mungkin akan terasa begitu utopis jika beranggapan bahwa suatu saat Islam akan bisa bersatu, dimana tidak akan ditemukan lagi perbedaan golongan, organisasi, partai, ataupun mazhab di dalamnya. Teramat sering kali ditemukan adanya suatu golongan yang menggunakan ayat-ayat Al-Qur'an sebagai pembenar atas apa yang mereka lakukan.

Kegelisahan akademik yang penulis rasakan dalam penyusunan jurnal ini adalah bahwa banyak sekali terdapat metode penafsiran AlQur'an, lantas pertanyaan yang akan muncul kemudian adalah metode manakah yang bisa memberikan pemahaman yang lebih komplek agar pemahaman terhadap ayat-ayat Al-Qur'an lebih memadai.

Dalam pendekatan pengkajian Islam, banyak sekali metode yang bisa dipergunakan sebagai pisau analisis untuk membedah seluk-beluk ajaran Islam (ayat-ayat Al-Qur'an). Salah satu metode yang bisa digunakan adalah pendekatan ilmu sosial profetik (ISP). Dan metode ISP inilah yang kemudian penulis gunakan untuk memahami makna ayat-ayat Al-Qur'an tersebut. Pendekatan ISP merupakan pendekatan yang digagas dan dikembangkan oleh Kuntowijoyo. Pendekatan ini lebih terfokus pada aspek yang bersifat empiris, historis, dan temporal. Dengan demikian, akan lebih terbuka kemungkinan adanya review, revisi dan rekonstruksi yang boleh hadir kapan saja dan terus menerus terhadap teks yang menjadi bahan kajiannya.

Disebabkan pendekatan yang penulis gunakan dalam penyusunan jurnal ini adalah pendekatan yang dibuat dan dikembangkan oleh seorang tokoh (Kuntowijoyo), maka dalam jurnal ini sedikit banyak akan dibahas mengenai riwayat kehidupan sang tokoh, karya-karya yang dihasilkan serta corak pemikirannya.

\section{B. Riwayat Kehidupan Kuntowijoyo}

Sebagai salah seorang cendekiawan muslim yang khas, Kuntowijoyo atau yang akrab disapa dengan Kunto, juga dikenal sebagai sejarawan, sastrawan dan budayawan. la dilahirkan di utara pesisir pantai 
selatan DIY, tepatnya di desa yang bernama Sorobayan, Sanden, Bantul Yogyakarta pada tanggal 18 September 1943. ${ }^{1}$ Kunto adalah anak kedua dari sembilan bersaudara ${ }^{2}$ dari pasangan suami-istri H.Abdul Wahid Sosromartojo dan $\mathrm{Hj}$. Warasti.

Bagi Kunto, corak perkembangan intelektualnya banyak dipengaruhi oleh Prof. Dr. Sartono Kartodirjo. Seorang dosen sekaligus sejarawan kenamaan yang juga menekuni bidang sejarah sosial, yang menurut pengakuan Kunto selalu menganjurkan untuk tidak percaya pada reduksionisme, menganjurkan plurikausalitas dan pendekatan multidimensional dalam sejarah. ${ }^{3}$

Kuntowijoyo mencapai puncak karir akademik sebagai dosen yaitu pada 21 Juli 2001. la dikukuhkan sebagai guru besar ilmu sejarah pada Fakultas Ilmu Budaya Universitas Gadjah Mada Yogyakarta dengan membawakan pidato pengukuhan berjudul "Periodisasi Sejarah Kesadaran Keagamaan Umat Islam di Indonesia yang Meliputi Mitos, Idiologi, dan Ilmu". ${ }^{4}$

Kendati menjalani hidup dalam keadaan sakit, semenjak mengalami serangan virus meningo enchepalitis pada 6 Januari 1992, dia terus berkarya sampai detik-detik akhir hayatnya. Prof Dr Kuntowijoyo meninggal dunia di Rumah Sakit Dr. Sardjito Yogyakarta, Selasa 22 Februari 2005 pukul 16.00 akibat komplikasi penyakit sesak napas, diare dan ginjal. ${ }^{5}$

Kuntowijoyo merupakan sosok yang produktif dan begitu konsisten dalam melahirkan karya-karya berbobot. Salah satu karya monomentalnya yaitu Paradigma Islam; Interpretasi untuk. Aksi (1991) yang menjadi magnum opusnya. Buku-buku Dinamika Sejarah Umat Islam Indonesia (1985); Budaya dan Masyarakat (1987); Identitas Politik Umat Islam (1987); Muslim Tanpa Masjid (2001); dan Selamat Tinggal Mitos, Selamat Datang Realitas (2002). Karya-karya ini dapat pengakuan luas dari berbagai kalangan media masa, perorangan dan masyarakat muslim lebih

\footnotetext{
${ }^{1}$ Kuntowijoyo, Islam Sebagai Ilmu; Epistemologi, Metodologi, dan Etika (Jakarta: Teraju, 2004), hlm. Sampul belakang.

${ }^{2}$ Ensiklopedi Tokoh Indonesia, "Kuntowijoyo; Sejarawan Beridentitas Paripurna", dalam Tokoh Indonesia. Com, Minggu, 11 Maret 2007, hlm. 2.

${ }^{3}$ Arif Subhan, "DR. Kuntowijoyo; Al-Qur'an Sebagai Paradigma”..........op.cit., hlm. 96.

4Pidato pengukuhan tersebut dimuat di Harian Republika 27,28, dan 29 Agustus 2001, dengan judul Mitos, Idiologi, Ilmu.

${ }^{5}$ Ensiklopedi Tokoh Indonesia, "Kuntowijoyo; Sejarawan...... op.cit., hlm. 1.
} 
luas. $^{6}$

Mengenai corak pemikiran Kuntowijoyo, Syafi'i Anwar menulis di dalam bukunya yang berjudul Pemikiran dan Aksi Islam Indonesia, memasukkan Kuntowijoyo dalam kelompok cendikiawan muslim dengan pemikiran transformatif. ${ }^{7}$ Pada sisi ini pemikiran Kuntowijoyo banyak didasarkan pada analisis sejarah sosial.

Menurut M. Dawam Raharjo, sebagai seorang cendekiawan muslim, pemikiran-pemikiran sosial-keagamaan Kuntowijoyo bertolak dari usaha pemahaman langsung terhadap ajaran-ajaran Islam, terutama Al-Qur'an, tanpa lewat tafsir-formal Al-Qur'an. Dalam hal ini dia berusaha menangkap makna-makna dalam Al-Qur'an dengan memakai kerangka ilmu. ${ }^{8}$

Fahri All dan Bahtiar Efendi menyatakan bahwa "Gagasangagasan Kuntowijoyo mewakili pandangan kekinian berdasarkan evolusi sejarah". Itu berarti gagasan-gagasannya telah memberikan kontribusi dalam memperkaya khazanah pemikiran Islam dan menjadi varian tersendiri spektrum intelektual Islam Indonesia.

Bahkan sebagaimana yang dikatakan M. Azhar, gagasan Kuntowijoyo sangat unik dan genuine yang tiada padanya dengan intelektual lainnya, di mana ia dapat mensintesiskan antara paradigma Islam maupun pendekatan ilmu-ilmu sosial Barat secara genuine. ${ }^{10}$

\section{Gambaran Umum Pendekatan ISP}

Ilmu Sosial Profetik atau biasa disingkat ISP adalah salah satu gagasan penting Kuntowijoyo. Baginya, ilmu sosial tidak boleh berpuas diri dalam usaha untuk menjelaskan atau memahami realitas dan kemudian memahaminya begitu saja tapi lebih dari itu, ilmu sosial harus juga mengemban tugas transformasi menuju cita-cita yang diidealkan masyarakatnya. Secara substansial kata "Profetik" dipakai sebagai kategori etis yang mengarah pada kesadaran para nabi (prophet) yang terlibat dalam sejarah 1) memanusiakan manusia, 2) membebaskan

\footnotetext{
${ }^{6}$ Kuntowijoyo, Identitas Politik Umat Islam (Bandung: Mizan, 1997), hlm.v-xii.

${ }^{7}$ Syafi'i Anwar, Pemikiran Politik dengan Paradigma Al-Qur'an; Sebuah Pengantar, dalam Identitas, hlm. xix.

${ }^{8}$ Dawam Raharjo, "Pengantar; Ilmu Sejarah Profetik dan Analisis Transformasi Masyarakat”, dalam Kuntowijoyo, Paradigma Islam....op.cit., hlm. 7.

${ }^{9}$ Fahri Ali dan Bahtiar Efendi, Merambah Jalan Baru Islam; Rekonstruksi Pemikiran Islam Indonesia Masa Orde Baru (Bandung: Mizan, 1986), hlm. 224.

${ }^{10} \mathrm{M}$. Azhar, "Pemikiran Politik Islam di Indonesia dari Idiologisasi, Objektifikasi Menuju Transformasi”, Milenium, No.l Tahun I, Januari-April 1998, hlm. 32.
} 
manusia, dan 3) membawa manusia berjalan menuju Tuhan. Dengan kata lain, upaya profetik mencoba menyatukan wahyu Tuhan dengan temuan pikiran manusia. la kemudian merumuskan tiga nilai dasar sebagai pijakan ilmu sosial profetik, yaitu: humanisasi, liberasi dan transendensi. ${ }^{11}$ Upaya para nabi untuk memanusiakan manusia kemudian disebut humanisme/emansipasi, membebaskan manusia disebut liberasi, dan membawa manusia berjalan menuju Tuhan disebut transendensi. ${ }^{12}$

\section{Humanisasi}

Dalam Ilmu Sosial Profetik, Humanisme adalah definisi teoritis dari 'Amar Ma'ruf yang diterjemahkan secara operasional menjadi memanusiakan manusia, menghilangkan "kebendaan", ketergantungan, kekerasan dan kebencian dari manusia. Humanisasi yang dimaksudkan di sini sesuai dengan semangat liberalisme Barat. Hanya saja perlu segera ditambahkan, jika peradaban Barat lahir dan bertumpu pada humanisme antroposentris, konsep humanisme Kuntowijoyo berakar pada humanisme teosentris. Karenanya, humanisasi tidak dapat dipahami secara utuh tanpa memahami konsep transendensi yang menjadi dasarnya.

Kuntowijoyo lalu mengusulkan humanisme teosentris sebagai ganti humanisme antroposentris untuk mengangkat kembali martabat manusia. Dengan konsep ini, manusia harus memusatkan diri pada Tuhan, tapi tujuannya adalah untuk kepentingan manusia (kemanusiaan) sendiri. Perkembangan peradaban manusia tidak lagi diukur dengan rasionalitas tapi transendensi. Humanisasi diperlukan karena masyarakat sedang berada dalam tiga keadaan akut yaitu dehumanisasi (obyektivasi teknologis, ekonomis, budaya dan negara), agresivitas (agresivitas kolektif dan kriminalitas) dan loneliness (privatisasi, individuasi).

\section{Liberasi}

Liberasi dalam Ilmu Sosial Profetik adalah definisi teoritis dari Nabiy Mungkar yang diterjemahkan secara operasional menjadi membebaskan manusia dari perbudakan. Liberasi di sini sesuai dengan prinsip sosialisme (marxisme, komunisme, teori

${ }^{11}$ http://id.wikipedia.org/wiki/ilmu sosial profetik. Diakses pada 16 Desember 2008.

${ }^{12}$ Kuntowijoyo, Paradigma Islam......, hlm. 1.283-285.

LITERASI, Volume. V, No. 1 Juni 2014 
ketergantungan, teologi pembebasan). Hanya saja Ilmu Sosial Profetik tidak hendak menjadikan liberasinya sebagai ideologi sebagaimana komunisme. Liberasi Ilmu Sosial Profetik adalah dalam konteks ilmu, ilmu yang didasari nilai-nilai luhur transendental. Jika nilai-nilai liberatif dalam teologi pembebasan dipahami dalam konteks ajaran teologis, maka nilai-nilai liberatif dalam Ilmu Sosial Profetik dipahami dan didudukkan dalam konteks ilmu sosial yang memiliki tanggung jawab profetik untuk membebaskan manusia dari kekejaman kemiskinan, pemerasan kelimpahan, dominasi struktur yang menindas dan hegemoni kesadaran palsu. Lebih jauh, jika marxisme dengan semangat liberatifnya justru menolak agama yang dipandangnya konservatif, Ilmu Sosial Profetik justru mencari sandaran semangat liberatifnya pada nilai-nilai profetik transendental dari agama yang telah ditransformasikan menjadi ilmu yang obyektif-faktual.

Kuntowijoyo menggariskan empat sasaran liberasi, yaitu sistem pengetahuan, sistem sosial, sistem ekonomi dan sistem politik yang membelenggu manusia sehingga tidak dapat mengaktualisasikan dirinya sebagai makhluk yang merdeka dan mulia.

\section{Transendensi}

Transendensi merupakan dasar dari dua unsur yang lain. Transendensi adalah definisi teoritis dari Yu'minuna billah yang diterjemahkan secara operasional menjadi membawa manusia menuju Tuhannya. Para penganjur ilmu-ilmu Profetik menekankan posisi penting transendensi setelah humanisme dan liberasi. Transendensi hendak menjadikan nilai-nilai transendental (keimanan) sebagai bagian penting dari proses membangun peradaban. Transendensi menempatkan agama (nilai-nilai Islam) pada kedudukan yang sangat sentral dalam Ilmu Sosial Profetik.

Transendensi adalah dasar dari humanisasi dan liberasi. Transendensi memberi arah kemana dan untuk tujuan apa humanisasi dan liberasi itu dilakukan. Transendensi dalam Ilmu Sosial Profetik di samping berfungsi sebagai dasar nilai bagi praksis humanisasi dan liberasi, juga berfungsi sebagai kritik. Dengan kritik transendensi, kemajuan teknik dapat diarahkan untuk mengabdi pada perkembangan manusia dan kemanusiaan, bukan pada kehancurannya. Melalui kritik transendensi, masyarakat akan 
dibebaskan dari kesadaran materialistik di mana posisi ekonomi seseorang menentukan kesadarannya menuju kesadaran transendental. Transendensi akan menjadi tolok ukur kemajuan dan kemunduran manusia. ${ }^{13}$

\section{Memahami Makna Ayat-ayat Al-Qur'an dengan Pendekatan ISP}

Dalam pandangan Syafi'i Anwar, yang dituangkan dalam pengantar Identitas Politik Islam, bahwa ide pokok dari pendekatan ISP dalam pengkajian studi Islam terdiri dari dua bagian:

\section{Transformasi Sosial dan Perubahan}

Ilmu social profetik yang ditawarkan Kuntowijoyo merupakan alternative terhadap kondisi status quo teori-teori social positivis yang pengaruhnya sangat kuat di kalangan intelektual dan akademisi di Indonesia. Sementara itu, ISP tidak hanya berkepentingan menjelaskan dan mengubah fenomena social, tetapi juga memberinya interpretasi, mengarahkan serta membawa perubahan bagi pencapaian nilai-nilai yang dianut oleh kaum muslim sesuai petunjuk Al-Qur'an, yakni emansipasi, humanisasi, liberasi, dan transendensi.

Dengan pendekatan ini, menurut syafi'i Anwar, bahwa Kuntowijoyo menginginkan Islam dapat terus-menerus mentrasformasikan masyarakat dengan berbagai aspeknya ke dalam skala-skala besar yang bersifat praktis dan teoritis. Kuntowijoyo tidak menaruh harapan yang besar pada penafsiran dan teologi yang bersifat literal, normatif, dan tidak memberi perubahan pada umat.

\section{Menjadikan Al-Qur'an Sebagai Paradigma}

Maksud dari menjadikan Al-Qur'an sebagai paradigma adalah bahwa Kuntowijoyo ingin agar umat Islam mampu menjadikan Al-Qur'an melakukan konstruksi pengetahuan yang memungkinkan kita memahami realitas sebagaimana dimaksud AlQur'an itu sendiri. Ini berarti bahwa Al-Qur'an mengkonstruksi pengetahuan yang memberi dasar untuk bertindak. Konstruksi demikian memungkinkan umat Islam menyusun system, termasuk system ilmu pengetahuan. Dengan demikian Al-Qur'an sekaligus memberikan gambaran aksiologis dan wawasan epistemologis sekaligus.

13 "Beberapa Gagasan Pokok Ilmu Sosial Profetik" dalam Wikipedia.com. Diakses pada 16 Desember2008

LITERASI, Volume. V, No. 1 Juni 2014 
Untuk bisa memahami makna ayat-ayat Al-Qur'an secara lebih memadai, maka Kuntowijoyo menganjurkan umat Islam untuk kembali kepada misi rasional dan empiris Islam. Upaya ini diperlukan guna mewujudkan program pembaharuan pemikiran untuk reaktualisasi Islam. Adapun program pembaharuan pemikiran yang ia maksudkan adalah: Program pertama, adalah perlunya dikembangkan penafsiran sosial struktural lebih dari pada penafsiran individual ketika memahami ketentuan-ketentuan tertentu di dalam Al-Qur'an. Program kedua, adalah mengubah cara berpikir subyektif ke cara berpikir obyektif. Program ketiga, adalah mengubah Islam yang normatif menjadi teoritis. Program keempat, adalah mengubah pemahaman yang a-historis menjadi historis. Dan program yang terakhir adalah bagaimana merumuskan formulasi-formulasi wahyu yang bersifat umum (general) menjadi formulasi-formulasi yang bersifat spesirik dan empiris". ${ }^{14}$

\section{Pengembangan penafsiran social structural}

Dalam memahami makna ayat-ayat Al-Qur'an, selama ini penafsiran yang kita lakukan adalah penafsiran yang lebih bersifat individual. Kelemahan dari penafsiran yang bersifat individual ini adalah kita tidak bisa mencari atau menemukan makna yang lebih mendalam dari ayat-ayat Al-Qur'an tersebut, sehingga ketika dihadapkan pada suatu persoalan yang bersifat lebih rumit atau persoalan yang baru ditemukan pada masa sekarang, kita kesulitan dalam memberikan solusi atas permasalahan itu.

Misalkan ayat tentang larangan hidup berlebih-lebihan. Ketika memahami ayat ini dengan menggunakan penafsiran individual, maka seringkali yang timbul atas penafsiran ayat tersebut adalah kutukan terhadap orang yang berfoya-foya, orang yang menghamburkan harta-bendanya, ataupun orang yang memiliki harta kekayaan yang begitu banyak, baik itu mobil mewah, rumah mewah yang hanya dijadikan sebagai penguat citra keberhasilan dirinya. Walaupun semua kecaman itu sah-sah saja dalam tataran hukum, akan tetapi itu tidak bisa dijadikan solusi.

Akan tetapi, jika ayat di atas dipahami dengan penafsiran social structural, maka persoalan yang lebih mendasar yang akan ditemukan adalah mencari sebab-sebab struktur kenapa gejala hidup mewah muncul dari konteks social dan system ekonomi. Dengan

${ }^{1414}$ Kuntowijoyo, Paradigma Islam...... hlm. 283-285. 
penafsiran ini, penafsiran terhadap gejala hidup mewah harus dikembangkan pada perspektif yang lebih luas yakni perspektif sosial dan structural. Kemungkinan besar kita akan menemukan akar permasalahan yang lebih esensial dari ayat tentang larangan hidup berlebih-lebihan yaitu terjadinya konsentrasi kapital (kekayaan) pada segelintir orang saja, akumulasi kapital ataupun disebabkan sistem kepemilikan sumber-sumber penghasilan atas dasar etika keserakahan. Maka dengan penafsiran yang bersifat sosial structural, setelah mengetahui akar permasalahan yang lebih esensial, kita bisa memberikan solusinya.

\section{Merubah Pola berfikir}

Baik disadari atau tidak, pola berfikir yang berkembang di kalangan umat Islam adalah pola berfikir yang bersifat subjektif. Oleh karena itu, Kuntowijoyo menganjurkan mengubah cara berfikir yang subjektif ke cara berfikir objektif, baik dalam memahami makna ayat-ayat Al-Qur'an itu sendiri ataupun yang lainnya. Menurut Kuntowijoyo, tujuan reorientasi berfikir secara objektif adalah untuk menyuguhkan Islam pada cita-cita objektif. ${ }^{15}$ Misalkan ayat-ayat Al-Qur'an tentang ketentuan zakat. Secara subjektif, ayat ini diarahkan atau ditujukan sebagai alat ataupun sarana untuk pembersihan harta kekayaan yang dimiliki, pembersihan jiwa dari pemilik harta, dll. Akan tetapi sisi objektif dari zakat sebenarnya adalah suatu upaya untuk mewujudkan kesejahteraan sosial dalam masyarakat. Kesejahteraan sosial bisa diwujudkan apabila setiap masyarakat memiliki daya beli. Daya beli akan bisa tercapai apabila ada distribusi kekayaan. Apabila keduanya telah terpenuhi, maka roda perekonomian (permintaan dan penawaran) bisa berjalan dengan baik.

\section{Merubah Pola Pemahaman Islam}

Dalam masyarakat Islam, pola kaum muslim dalam memahami ayat-ayat Al-Qur'an lebih bersifat normatif. Oleh karena itu, dalam pendekatan ISP, Kuntowijoyo menganjurkan agar mengubah pola Islam yang normatif menjadi Islam teoritis. Secara normatif orang mungkin dapat mengembangkan tafsiran moral ketika memahami konsep tentang fuara dan konsep masakin, kaum fakir dan miskin. Jika menggunakan pendekatan yang bersifat

${ }^{15}$ Ibid., hlm. 284. 
normatif, maka kaum fakir dan miskin paling-paling hanya akan dilihat sebagai orang-orang yang perlu dikasihani, sehingga kita wajib memberikan kepada mereka zakat, infak dan sadaqah.

Berbeda halnya jika menggunakan pendekatan teoritis. Kemungkinan besar kita akan menemukan konsep tentang fakir dan miskin dalam konteks yang lebih real, lebih factual, sesuai dengan kondisi-kondisi sosial ekonomi dan kultural.

\section{Mengubah Pola Pemahaman Sejarah}

Selama ini, sebagaimana yang kita rasakan, umat Islam memahami yang tertuliskan dalam Al-Qur'an cendrung bersifat a histories. Oleh karena itu, Kuntowijoyo menganjurkan agar umat Islam mengubah pemahaman yang a histories menjadi histories ${ }^{16}$. Pemahaman histories sangat perlu dilakukan ketika hendak mengkaji makna ayat-ayat Al-Qur'an. Kalau seandainya kita lebih teliti ketika memahami maksud Al-Qur'an menceritakan kisah-kisah tersebut maka kita akan menemukan bahwa maksudnya adalah agar kita bersifat histories.

Misalkan kisah tentang bangsa Israel yang tertindas pada zaman Fir'aun. Kisah ini sering dipahami pada konteks masa lalu. Kalau seandainya kita berfikir bahwa apa yang disebut sebagai orang tertindas, maka kita akan menemukannya pada setiap zaman dan pada setiap sistem sosial. Baik itu pada zaman feodalisme, sosialisme, kapitalisme maupun Islam.

7. Membuat Format Formulasi Penafsiran yang Spesifik dan Empiris.

Hal lain yang bisa digunakan dari pendekatan ISP Kuntowijoyo agar bisa memahami makna ayat-ayat Al-Qur'an secara lebih mendalam adalah dengan membuat penafsiran dalam format formulasi-formulasi yang spesifik dan empiris. Format formulasi penafsiran ini sangat sesuai ketika memahami ayat yang artinya bersifat umum dan normatif.

Misalkan ayat mengenai kecaman Allah terhadap orangorang yang melakukan sirkulasi kekayaan hanya pada kaum kaya. Kalau dicermati secara sekilas, penjelasan ayat ini bersifat normatif dan umum. Oleh karena itu, perlu dirumuskan secara spesifik dan empiris. Itu artinya bahwa kita perlu menerjemahkan ayat tersebut ke dalam dataran realitas empiris. Jadi, kemudian ayat tersebut bisa 
dipahami sebagai kecaman Allah terhadap praktek monopoli dan oligopoly dalam kehidupan perekonomian, politik, ataupun adanya penguasaan kekayaan oleh kalangan tertentu di lingkungan elit berkuasa.

\section{E. Kesimpulan}

Dari pemaparan di atas dapat disimpulkan bahwa penafsiran terhadap ayat-ayat Al-Qur'an tidak ada yang bersifat permanen. Penafsiran tersebut akan selalu berubah sesuai dengan kondisi atau konteks ketika ayat tersebut ditafsirkan. Begitu juga, bahwa tidak ada penafsiran terhadap ayat Al-Qur'an yang mutlak akan kebenarannya. Penafsiran Al-Qur'an dengan pendekatan ISP akan memiliki corak yang humanis, liberalis, dan transcendental.

Untuk memahami makna ayat-ayat Al-Qur'an secara lebih mendalam, maka perlu memperhatikan beberapa hal. pertama, adalah perlunya dikembangkan penafsiran sosial struktural lebih dari pada penafsiran individual ketika memahami ketentuan-ketentuan tertentu di dalam Al-Qur'an. Program kedua, adalah mengubah cara berpikir subyektif ke cara berpikir obyektif. Program ketiga, adalah mengubah Islam yang normatif menjadi teoritis. Program keempat, adalah mengubah pemahaman yang a-historis menjadi historis. Dan program yang terakhir adalah bagaimana merumuskan formulasi-formulasi wahyu yang bersifat umum (general) menjadi formulasi-formulasi yang bersifat spesifik dan empiris 


\section{DAFTAR PUSTAKA}

Azhar, M. Pemikiran Politik Islam di Indonesia dari Idiologisasi, Objektifikasi Menuju Transformasi, Melenium, No.l Tahun I, Januari-April 1998

Beberapa Gagasan Pokok Ilmu Sosial Profetik, dalam Wikipedia.com. Diakses pada 16 Desember 2008.

Ensiklopedi Tokoh Indonesia, Kuntowijoyo; Sejarawan Beridentitas Paripurna, dalam Tokoh Indonesia. Com, Minggu, 11 Maret 2007.

Fahri AH dan Bahtiar Efendi. 1986. Merambah Jalan Baru Islam; Rekontruksi Pemikiran Islam Indonesia Masa Orde Baru. Bandung: Mizan.

http://id.wikipedia.org/wiki/ilmu sosial profetik. Diakses pada 16 Desember 2008.

Kuntowijoyo. Dinamika Sejarah Umat Islam Indonesia, Yogyakarta: Shalahuddin Press, 1985 , Identitas Politik Umat Islam, Bandung: Mizan, 1997

Islam Sebagai Ilmu; Epistimologi, Metodologi, dan Etika. Jakarta: Teraju, 2004 , Paradigma Islam; Interpretasi Untuk Aksi, Bandung: Mizan, 1991 